\title{
Postprandial biliary and pancreatic secretion during profound inhibition of gastric secretion in humans
}

\author{
A Lanzini, D Facchinetti, M G Pigozzi, A Wuhrer, A Saleri
}

\begin{abstract}
This study assessed the effect of profound inhibition of gastric secretion by an $\mathbf{H}_{2}$ antagonist on postprandial gastric emptying of acid and chyme, and on bile acid and pancreatic enzyme secretion under physiological conditions in humans. Six subjects were studied before and while they were given famotidine $(40 \mathrm{mg})$. This study combined a continuous intestinal perfusion technique using ${ }^{14} \mathrm{C}$-polyethylene glycol $\left({ }^{14} \mathrm{C}\right.$-PEG) as duodenal recovery marker, with intermittent sampling of gastric content using PEG 4000 as meal marker. During the three hour study, the area under the curve for gastric acid output decreased from mean (SEM) $88.9(7.6) \mathrm{mmol}$ for those not receiving treatment, to 21.2 $(2 \cdot 7) \mathrm{mmol}$ for subjects receiving famotidine $(p<0.01)$. The corresponding values for the rate of acid delivery into the duodenum decreased from $65.2(11.9)$ to $16.6(2.9) \mathrm{mmol}$ $(p<0.05)$, and those for the rate of gastric emptying of chyme remained unchanged for the group receiving no treatment and during famotidine $(1040(200) v 985(160) \mathrm{ml}$ respectively, NS). Duodenal bile acid and trypsin output remained unchanged (area under the curve, $457(128) v 373(86) \mathrm{umol} / \mathrm{kg}$ and 5022 (565) $v 5058$ (400) IU/kg respectively, NS) receiving no treatment and during famotidine. It is concluded that profound inhibition of postprandial gastric acid secretion by antisecretory drugs is not accompanied by changes in biliary and pancreatic secretion, mainly because the gastric emptying of chyme is unaffected.
\end{abstract}

(Gut 1993; 34: 1607-1611)

Administration of histamine $\mathrm{H}_{2}$ receptor antagonists reduces basal and stimulated gastric secretion in a dose related manner in humans, but little information is available on their effect on biliary and pancreatic secretion. Although studies entailing measurement of intraduodenal concentration of biliary and pancreatic secretions have reported no change, ${ }^{1-4}$ studies with measurement of secretion rates have given discrepant results. On the one hand, both intravenous metiamide infusion $(100 \mathrm{mg} / \mathrm{h})^{5}$ and oral cimetidine $(600 \mathrm{mg})$ administration ${ }^{6}$ have been reported to reduce secretin cholecystokinin (CCK) and sham feeding stimulated pancreatic enzyme secretion in healthy humans. This effect of $\mathrm{H}_{2}$ antagonists on pancreatic secretion is probably indirect, because both the pancreas and the gall bladder have been reported to lack functional histamine $\mathrm{H}_{2}$ receptors in dogs ${ }^{7}$ and in humans, ${ }^{8}$ respectively. On the other hand, low dose cimetidine $(300 \mathrm{mg})^{9}$ has been reported to have no effect on postprandial biliary and pancreatic secretion in patients with duodenal ulcer.

Methodological differences may account for the discrepancies reported above. Only studies with high dose administration of $\mathrm{H}_{2}$ antagonists, and profound inhibition of gastric secretion ${ }^{56}$ have reported reduced pancreatic enzyme secretion. In these studies, however, biliary and pancreatic secretion were measured under nonphysiological stimuli such as intravenous secretin CCK or sham feeding. By contrast, the only study entailing physiological stimulation of biliary and pancreatic secretion, using a meal, reported no effect on duodenal bile acid and trypsin output, ${ }^{9}$ but this study used a low dose of cimetidine (200-300 mg), which reduced peak acid delivery into the duodenum by only about $50 \%$ compared with no treatment.

The aim of our study was to assess the effect of profound inhibition of gastric secretion on postprandial duodenal bile acid and trypsin output after physiological stimulation in humans. We measured simultaneously gastric emptying of chyme and acid load into the duodenum - that is, the two main intraluminal factors known to regulate biliary and pancreatic secretion in response to a meal. To achieve these aims we used the intestinal perfusion technique developed by Malagelada et $a l .{ }^{10}$ This technique entails continuous duodenal aspiration during duodenal perfusion of ${ }^{14} \mathrm{C}$-polyethylene glycol $\left({ }^{14} \mathrm{C}-\mathrm{PEG}\right)$ given as an intestinal recovery marker, combined with intermittent gastric aspiration using unlabelled PEG added to a test meal as a marker of gastric content. We applied this technique to six subjects studied on two successive days, random order, after a potent $\mathrm{H}_{2}$ antagonist, famotidine $40 \mathrm{mg}$, was given orally, and after no treatment.

\section{Subjects and methods}

SUBJECTS

We studied six subjects (three men and three women, age range 40-67 years) referred to our clinic with dyspepsia. For each subject, upper gastrointestinal endoscopy and abdominal ultrasonography were normal, and routine blood tests were within the normal limits for our laboratory. The study protocol was in accordance with the Helsinki Declaration, and informed consent was obtained from each subject.

\section{EXPERIMENTAL DESIGN}

All subjects were studied on two successive days, after no treatment and after they had been given famotidine. Four subjects were allocated to receive no treatment first, and two subjects 
to receive famotidine first. The treatment comprised $40 \mathrm{mg}$ famotidine (MS\&D) given orally two hours before the study, a regimen reported to inhibit pentagastrin stimulated gastric acid secretion by $90 \%$ in humans. ${ }^{11}$

\section{CLINICAL PROCEDURE}

On the day of the study, the patients were admitted after fasting to a clinical investigation side room. A radio-opaque three lumen nasoduodenal tube was inserted under fluoroscopic control. The proximal outlet was positioned in the body of the stomach for aspiration of the gastric contents. The duodenal perfusion tube was positioned opposite to the ampulla of Vater, and the duodenal aspiration tube was positioned at the ligament of Treitz, $20 \mathrm{~cm}$ beyond the perfusion outlet. The internal diameter was $2.5 \mathrm{~mm}$ for the duodenal aspiration tube, and $1 \mathrm{~mm}$ for the other two tubes. Radio-opaque markers were attached to the outlet of each tube to assist fluoroscopic positioning. The position of the tube was checked before the start and at the end of the duodenal perfusion study.

A liquid meal (Lundh test meal) was given
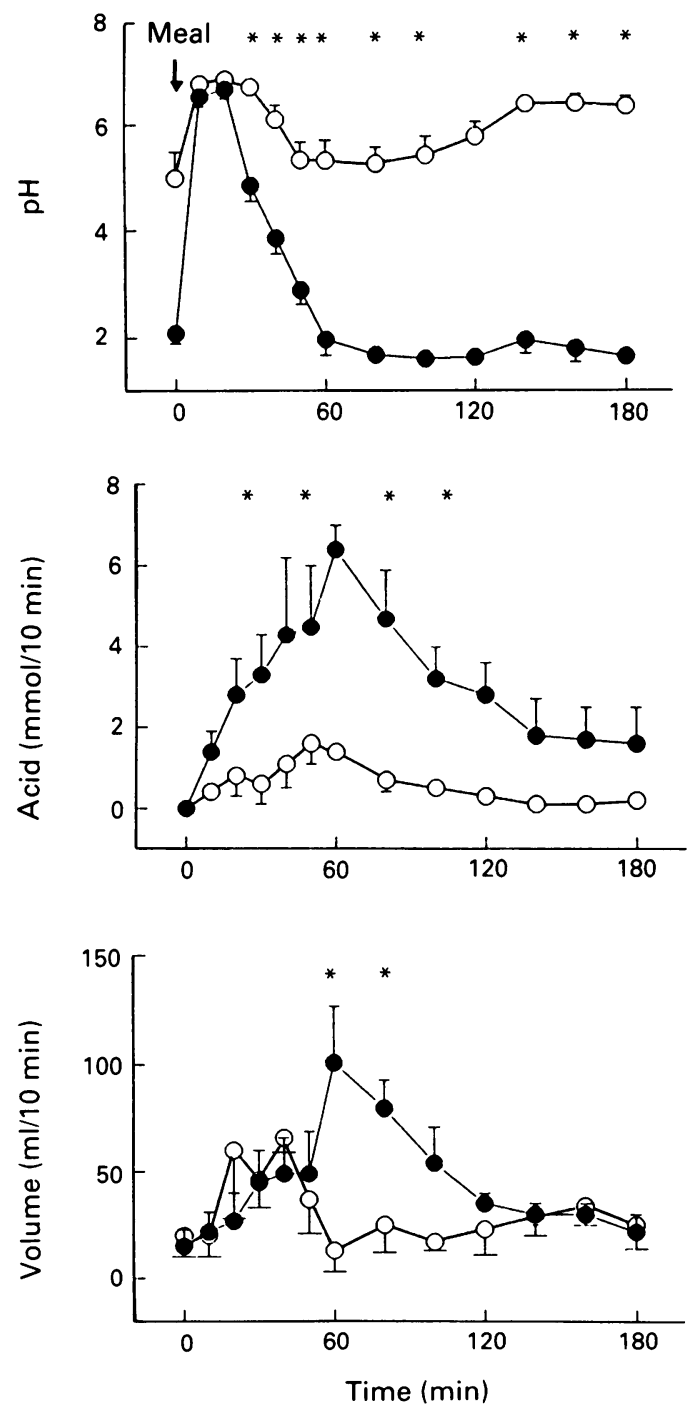

Figure 1: Gastric pH, acid, and volume secretion before (O) and during $(\bigcirc)$ acute famotidine treatment given two hours before a meal. ${ }^{\star}=p<0.05$. over a period of 10 minutes, at the end of the equilibration period for the duodenal perfusion (see below). The meal consisted of $15 \mathrm{~g}$ Casilan, $40 \mathrm{~g}$ glucose, and $18 \mathrm{~g}$ corn oil diluted in $220 \mathrm{ml}$ water ( $\mathrm{pH} 7 \cdot 20$ ), and contained 5 g PEG (MW 4000) as meal marker.

The duodenal perfusate contained $10 \mu \mathrm{Ci}{ }^{14} \mathrm{C}$ PEG (Amersham, UK) dissolved in 1 litre of normal saline. The perfusate was magnetically stirred and perfused intraduodenally at a constant rate $(2.5 \mathrm{ml} / \mathrm{min})$ by a peristaltic pump (model 501, Watson Marlow, UK). The duodenal perfusion started in the morning immediately after intubation, and after allowing 60 minutes for equilibration, the liquid meal was given orally. Duodenal content was aspirated by siphonage at 10 minute intervals during the first postprandial hour, and at 20 minute intervals during the second and third postprandial hour. About $10 \mathrm{ml}$ duodenal aspirate was retained for analysis, and the rest was returned to the intestine through the duodenal aspiration tube at the end of the study to prevent depletion of the bile acid pool.

During the equilibration period, the gastric content was aspirated continuously through the gastric tube by syringe. After administration of the liquid meal, the gastric content was aspirated at 10 minute intervals during the first postprandial hour, and at 20 minute intervals thereafter. A sample of gastric content $(20-50 \mathrm{ml})$ was aspirated, mixed by agitation, and $5 \mathrm{ml}$ was retained for analysis. The remainder was gently returned to the stomach. Gastric aspiration was carried out five minutes before duodenal sampling to allow for transit time of the gastric content into the duodenum..$^{10}$ At the end of the three hour study, the gastric content remaining in the stomach was aspirated as completely as possible, and $50 \mathrm{ml}$ saline was infused and aspirated from the stomach to ensure complete recovery of the meal marker.

LABORATORY METHODS

The $\mathrm{pH}$ of gastric and duodenal aspirate was measured using a pH meter (model PHM 82, Radiometer, Copenhagen) calibrated at $\mathrm{pH} 1.68$ and $7 \cdot 00$. Acidity in gastric aspirate was measured by titration to $\mathrm{pH} 7 \cdot 2$ (the $\mathrm{pH}$ of the meal) using $0.05 \mathrm{~N} \mathrm{NaOH}$. PEG concentration in gastric and in duodenal aspirate was measured by the turbidometric method of Hyden. ${ }^{12}$ Bile acid concentration in duodenal aspirate was measured by the 3- $\alpha$-hydroxysteroid dehydrogenase method of Talalay,,$^{13}$ and trypsin concentration was measured using a titrimetric method as previously described. ${ }^{14}{ }^{14} \mathrm{C}$ Activity in duodenal aspirate was measured using a $\beta$ counter (model LS 2800 Beckman, USA) equipped with $\mathrm{H}$ number facilities by adding 100 ul duodenal aspirate to $10 \mathrm{ml}$ liquid scintillation fluid (Beckman Ready Micro).

STATISTICAL ANALYSIS

Calculations were carried out using the formulas described by Malagelada et al. ${ }^{10}$ Comparison of the amount of PEG recovered from the stomach and duodenum (the second after correction by 

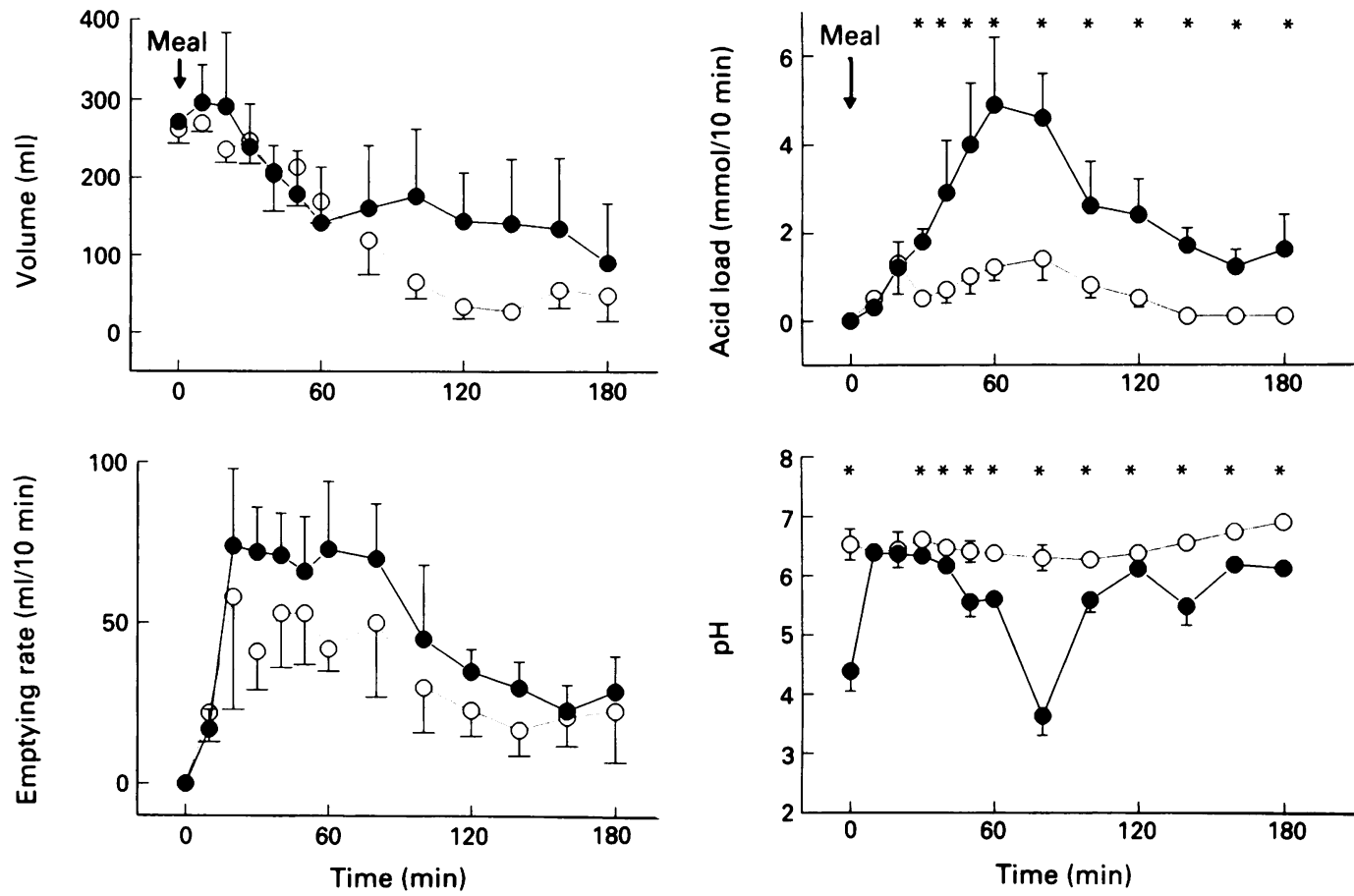

Figure 2: Volume of gastric content and gastric emptying rate before $(O)$ and during $(\bigcirc)$ acute famotidine treatment.

duodenal marker recovery), with the amount of PEG added to the meal provided an opportunity to validate the intestinal perfusion technique.

Results were expressed as mean values (SEM). Measurement of area under the curve was carried out by elemental geometry. Differences between paired findings were tested using non-parametric analysis of variance (Friedmann test). A p value $<0.05$ was accepted as a statistically significant difference.

\section{Results}

\section{VALIDATION STUDIES}

During the procedure, the gastric aspiration tube was blocked in one subject during the baseline study, and the duodenal aspiration tube was blocked in another subject during famotidine administration. Duodenal recovery of the meal marker was $88 \%, 78 \%, 90 \%, 108 \%$, $138 \%, 99 \%, 108 \%, 86 \%, 118 \%$, and $78 \%$ respectively in each of the 10 individual studies completed, and mean value was $99(8) \%$.

\section{GASTRIC PH, ACID OUTPUT, AND SECRETORY} VOLUME (Fig 1)

During the baseline studies, mean gastric $\mathrm{pH}$ rose from $2.09(0.20)$ preprandially to a maximum $6.69(0 \cdot 19)$ at 20 minutes postprandially. It declined progressively during the first postprandial hour to reach a plateau value at about $1.6 \mathrm{pH}$ units during the second and third postprandial hour. During famotidine, the profile of gastric $\mathrm{pH}$ diverged from that seen during the baseline studies from the 30th postprandial minute, and mean value never fell below $5.0 \mathrm{pH}$ units.

During the baseline studies, the mean value of gastric acid output reached a peak value of 6.4 $(0 \cdot 6) \mathrm{mmol} / 10 \mathrm{~min}$ during the first postprandial

Figure 3: Duodenal acid load and $\mathrm{pH}$ before (O) and during (O) acute famotidine treatment. ${ }^{\star}=p<0.05$.

hour and progressively decreased thereafter. The corresponding mean values during famotidine never exceeded $1.6(0.5) \mathrm{mmol} /$ $10 \mathrm{~min}$ during the whole study, and differences between paired time intervals during baseline and famotidine studies were statistically significant at $30,50,80$, and 120 minutes postprandially. Mean value for area under the curve decreased from $88.9(7 \cdot 6)$ to $21.2(2.7) \mathrm{mmol}$ $(\mathrm{p}<0.001)$ in baseline and famotidine studies respectively.

The total amount of acid produced by the stomach in each study was $55.4 v 11.8 \mathrm{mmol}$, 36.1 v $14.9 \mathrm{mmol}, 65.3$ v $15.5 \mathrm{mmol}, 48.8 v$
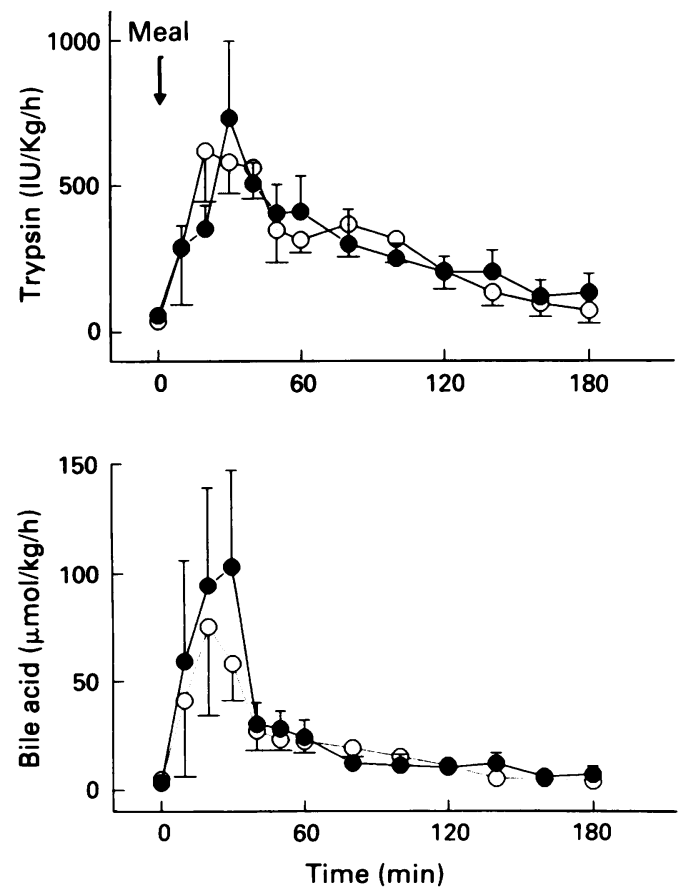

Figure 4: Trypsin and bile acid output into duodenum before (O) and during $(\mathrm{O})$ acute famotidine treatment. 
$10.9 \mathrm{mmol}$, and $25.8 v 9.7 \mathrm{mmol}$ during the baseline and famotidine studies respectively. The mean value decreased from $46.3(7 \cdot 0)$ to $12.6(1 \cdot 1) \mathrm{mmol}(\mathrm{p}<0 \cdot 01)$, respectively, corresponding to $73 \%$ inhibition of gastric acid production by famotidine.

The volume of gastric secretion was also reduced during famotidine by comparison with baseline studies, but only at 60 and 80 minutes postprandially (101 (26) $v 13(10) \mathrm{ml}, \mathrm{p}<0.05$, and 80 (13) $v 25(13) \mathrm{ml}, \mathrm{p}<0.05$, respectively). Mean values for area under the curve decreased from 1220 (149) to 806 (103) $\mathrm{ml}$ (NS).

\section{VOLUME OF GASTRIC CONTENT AND RATE OF GASTRIC EMPTYING (Fig 2)}

The volume of gastric content was similar in the baseline and in the famotidine studies, and differences between paired time intervals did not reach statistical significance. Values for area under the curve were also similar in baseline and famotidine studies (3269 (850) $\mathrm{ml} v 2209$ (409) $\mathrm{ml}$, NS, respectively). There was a tendency for gastric emptying rate to be lower on famotidine than on no treatment studies, but differences between paired time intervals were not statistically significant. Mean values for area under the curve were also similar $(1040(200) \mathrm{ml}$ $v 985(160) \mathrm{ml}$, NS, in baseline and famotidine studies, respectively).

\section{ACID LOAD INTO THE DUODENUM AND DUODENAL PH (Fig 3)}

The rate of acid load into the duodenum was lower during famotidine treatment than on no treatment from 30 minutes after the meal onwards. Mean value for area under the curve decreased from $65.6(11.9) \mathrm{mmol}$ during baseline studies, to $16.6(2.9) \mathrm{mmol}$ during famotidine $(\mathrm{p}<0.05)$.

Mean value for duodenal $\mathrm{pH}$ was consistently higher during famotidine than on no treatment.

\section{DUODENAL TRYPSIN AND BILE ACID OUTPUT}

(Fig 4)

Mean value for duodenal trypsin output on no treatment rose from $57(25) \mathrm{IU} / \mathrm{kg} / \mathrm{h}$ to a peak of $732(265) \mathrm{IU} / \mathrm{kg} / \mathrm{h}$ at 30 minutes postprandially, and declined progressively thereafter. The profile during famotidine was similar, with peak value $(620)(175) \mathrm{IU} / \mathrm{kh} / \mathrm{h})$ at 20 minutes postprandially. The area under the curve for duodenal trypsin output was also similar to that for no treatment and after famotidine (5022 (565) v 5058 (400) IU $/ \mathrm{kg}$ respectively, NS).

Mean value for duodenal bile acid output on no treatment reached a peak of 103 (44) $\mathrm{umol} / \mathrm{kg} / \mathrm{h}$ at 30 minutes postprandially, and declined progressively thereafter. The profile on famotidine was similar, with peak value of 75 (41) $\mathrm{umol} / \mathrm{kg} / \mathrm{h}$ was reached at 20 minutes postprandially. The area under the curve for duodenal bile acid output was 457 (128) umol $/ \mathrm{kg}$ during baseline studies, and remained unchanged at 373 (86) umol/kg during famotidine (NS).

\section{Discussion}

Duodenal recovery of the meal marker by means of the intestinal perfusion technique was virtually complete in this study. The mean value for recovery ( $99 \%$ ) was similar to that previously reported by us (101\% and $102 \%)$ for duodenal recovery of a gall bladder bile marker, ${ }^{14}$ is further confirming the validity of the intestinal perfusion technique. We have reported good reproduceability for trypsin and bile acid duodenal secretion on two successive days. ${ }^{14}$

To assess the relation between gastric and biliopancreatic secretory functions in humans, we have measured changes in these functions during administration of a potent inhibitor of gastric secretion, famotidine. Postprandial gastric acid secretion was reduced by a mean value of $73 \%$ during famotidine administration in comparison with no treatment (Fig 1). This profound inhibition of gastric acid secretion was less than that reported for the same dose of famotidine during pentagastrin stimulation in humans $\left(73 \% v 90 \%\right.$, respectively), ${ }^{11}$ a finding which supports the concept that postprandial inhibition of gastric secretion by $\mathrm{H}_{2}$ antagonists is partially surmountable by physiological stimuli. ${ }^{16-19}$

We have shown that profound inhibition of gastric secretion during digestion of a physiological meal has no effect on biliary and pancreatic secretion in humans (Fig 4). By contrast, other studies have shown that inhibition of gastric secretion interferes with the cephalic, gastric or the intestinal phases of pancreatic secretion in studies where these phases have been assessed separately. Thus, inhibition of gastric acid secretion by cimetidine has been reported to reduce the cephalic phase of pancreatic enzyme secretion (using sham feeding) by $40 \%$ in humans. ${ }^{6}$ Intravenous infusion of metiamide reduced pancreatic enzyme secretion stimulated by intravenous administration of the two main hormones participating in the intestinal phase of secretion, secretin, and CCK. ${ }^{5}$ The volume of gastric content has been reported to influence pancreatic secretion, a phenomenon mediated by gastric distension by neural pathways. ${ }^{20-23}$ Our findings clearly suggest that in humans the main method by which the stomach regulates biliary and pancreatic secretion during digestion of a physiological meal does not entail acid secretion, a finding consistent with results in dogs treated with omeprazole. ${ }^{24}$ Furthermore, these findings imply that the effect of acid in enhancing the cephalic and intestinal phase of pancreatic secretion is of little physiological importance in the complex interplay between humoral and nervous mechanisms activated by the digestion of a meal.

The methods used in this study allowed us to assess factors other than acid secretion known to affect biliary and pancreatic secretion. We found that the reduced acid secretion on famotidine was accompanied by only a slight reduction in the gastric emptying of chyme, which was accompanied by a similar reduction in the volume of gastric content. (Fig 2). This suggested that the fractional gastric emptying rate was unchanged on famotidine. The marginal changes in gastric emptying of chyme provide an 
explanation for the unchanged biliary and pancreatic secretion during famotidine treatment. This is because the rate of gastric emptying of chyme into the intestine is the main stimulus to endogenous CCK release, ${ }^{25}$ and to enteropancreatic reflexes activated by volume receptors in the duodenum. ${ }^{26}$

Longstreth et $a l^{9}$ have reported similar results to us with the same methods, but a different meal (solid), in patients with duodenal ulcer during low dose cimetidine (200-300 mg) treatment. In their study, however, the peak acid load to the duodenum during treatment $(2.5 \mathrm{mmol} / 10 \mathrm{~min})$ was higher than that reported in our study $(1.4 \mathrm{mmol} / 10 \mathrm{~min}$, Fig 3). This difference is important, because a persistent acid load to the duodenum during treatment may itself stimulate pancreatic secretion by enteropancreatic cholinergic reflexes, a phenomenon described in dogs during low dose intraduodenal instillation of $\mathrm{HCl}^{27}{ }^{28}$ Our evidence for a lack of effect of $\mathrm{H}_{2}$ antagonist on biliary and pancreatic secretion is therefore stronger.

In conclusion, our study shows that during digestion of a physiological meal, biliary and pancreatic secretion are unaffected in humans by potent anti-secretory drugs mainly because gastric emptying of chyme is unaffected. From a clinical point of view, our study confirms that famotidine may be safely used for treatment of peptic ulcer disease, and as adjuvant treatment in combination with pancreatic extracts in patients with pancreatic insufficiency.

Part of this work was presented at the European Digestive Disease Week in Vienna, 5-9 June 1990, and published in abstract form the European Fournal of Gastroenterology and Hepatology 1990; 2 (suppl 1): S55. The authors wish to thank Mrs Alessandra Rossi for skilful technical assistance.

1 Maudgal DP, Lawrence D, Snaderson FM, Northfield TC. Effect of cimetidine on pancreatic and biliary function in man. Brf Clin Pharmacol 1979; 8: 229-31.

2 Konturek SJ, Obtulowicz W, Kwiecien N, Kopp B, Olesky J. Kinetics and duration of action of ranitidine on gastric secretion and its effect on pancreatic secretion in duodenal ulcer patients. Scand $\mathcal{F}$ Gastroenterol 1981; 16 (suppl 69): 91-7.

3 Chremos AN. Pharmacodynamics of famotidine in humans. Am f Med 1986; 81 (suppl 4B): 3-7.

4 Galmiche JP, Colin R, Al-Saati MN, Geffroy Y. Effect of cimetidine on pancreatic exocrine secretion. Lancet 1977; 647-8.

5 Thjodleifsson B, Wormsley KG. Effect of metiamide on the response to secretin and cholecystokinin in man. Gut 1975; 16: $33-5$.
6 Anagnostides A, Chadwick VS, Selden AC, Maton PN. Sham feeding and pancreatic secretion. Evidence for direct vagal stimulation of enzyme output. Gastroenterology 1984;87. 109-14.

7 Bertaccini $\mathrm{G}$, Coruzzi G. Histamine $\mathrm{H}_{2}$-receptor agonists and antagonists on pancreatic exocrine secretion of the dog. Agents Actions 1985; 16: 211-4.

8 Lennon F, Feeley TM, Clanachan AS, Scott GW. Effects of histamine receptor stimulation on diseased gallbladder and cystic duct. Gastroenterology 1984; 87: 257-62.

9 Longstreth GF, Go VLW, Malagelada J-R. Postprandia gastric, pancreatic, and biliary response to histamine $\mathrm{H}_{2}$ receptor antagonists in active duodenal ulcer. Gastroenterology 1977; 72: 9-13.

10 Malagelada J-R, Longstreth GF, Summerskill WHI, Go VLW. Measurement of gastric functions during digestion of ordinary solid meals in man. Gastroenterology 1976; 70: 203-10.

11 Smith JL, Gamal MA, Chremos AN, Graham DY. Famotidine, a new $\mathrm{H}_{2}$ receptor antagonist. Effect on
parietal, nonparietal, and pepsin secretion in man. Dig Dis parietal, nonparietal,

12 Hyden S. A turbidometric method for the determination of higher polyethylene glycols in biological materials. Kungl Lantbrukshogskolans Annaler 1955; 22: 139-45.

13 Talalay P. Enzymic analysis of steroid hormones. Method Bioch Anal 1960; 8: 119-43.

14 Lanzini A, Facchinetti D, Hall N, Northfield TC. Effect of ursodeoxycholic acid on pancreatic enzyme secretion and gallbladder emptying. Pancreas 1990; 5: 128-35.

15 Lanzini A, Jazrawi RP, Northfield TC. Simultaneous quantitative measurements of absolute gallbladder storage and emptying during fasting and eating in humans. Gastroenterology 1987; 92: 852-61.

16 Merki HS, Witzel L, Kaufmann D, Kempf M, Neuman J Röhnel J, et al. Continuous intravenous infusions of famotidine maintain high intragastric $\mathrm{pH}$ in duodenal ulcer. Gut 1988; 29: 453-7.

17 Merki HS, Halter F, Wilder-Smith C, Allemann P, Witze $L$, Kempf $M$, et al. The effect of food on $\mathrm{H}_{2}$ receptor blockade in normal subjects and duodenal ulcer patients. Gut 1990; 31: 148-50.

18 Johnston DA, Wormsley KG. The effect of food on ranitidineinduced inhibition of nocturnal acid secretion. Aliment Pharmacol Therap 1988; 2: 507-11.

19 Merki HS, Wilder-Smith CH, Walt RP, Halter F. The cephalic and gastric phases of gastric secretion during $\mathrm{H}_{2-}$

20 White TT, Lundh G, Magee DF. Evidence for the existence of a gastropancreatic reflex. Am F Physiol 1960; 198: 725-8.

21 White TT, McAlexander RA, Magee DF. The effect of gastric distension on duodenal aspirates in man. Gastroenterology $1953 ; 44: 48-51$

22 Debas HT, Yamagishi T. Evidence for a pyloropancreatic reflex for pancreatic exocrine secretion. Am $\mathcal{F}$ Physiol 1971 234: G468-71.

23 Krabisz BR, Miller LJ, Di Magno EP, Go VLW. In the absence of nutrients, pancreatic-biliary secretion in the jejunum do not exert feedback control of human pancreatic or gastric function. $\mathcal{F} \mathrm{Lab}$ Clin Med 1980; 95: 13-8.

24 Konturek SJ, Cieszkowski M, Kwiecien N, Konturek J Tasler J, Bilski J. Effect of omeprazole, a substituted benzimidazole, on gastrointestinal secretions, serum gastrin, and gastric mucosal blood flow in dogs. Gastroenterology 1984; 86: 71-7.

25 Colombel JF, Sutton A, Chayvialle JA, Modigliani R. Cholecystokinin release and biliopancreatic secretion in Cholecystokinin release and biliopancreatic secretion in response to selective perfusion of the duode

26 Dooley CP, Valenzuela JE. Duodenal volume and osmoreceptors in the stimulation of human pancreatic secretion. Gastroenterology 1984; 86: 23-7.

27 Singer MV. Pancreatic secretory response to intralumina stimulants: a review. Scand $\mathcal{F}$ Gastroenterol 1987; 22 (supp 139): 1-13.

28 Singer MV, Solomon TE, Rammert $\mathrm{H}$, et al. Effect of atropine on pancreatic response to HCL and secretin. Am f Physiol 1981; 240: G376-80. 